\title{
SEKS BEBAS MENURUT REMAJA PUTRI DI SMA N 1 SRAGI
}

\author{
Is Susiloningtyas ${ }^{1}$, Iga Retia Mufti ${ }^{2}$ \\ ${ }^{1}$ Prodi D3 Kebidanan Fakultas Kedokteran Universitas Islam Sultan Agung Semarang \\ Email: issusiloningtyas@gmail.com
}

\begin{abstract}
ABSTRAK
Remaja merupakan generasi penerus pembentuk keluarga. Data demografi menunjukkan bahwa remaja merupakan populasi yang besar dari penduduk dunia. Seperlima dari penduduk dunia adalah remaja berumur 1019 tahun. Di Indonesia jumlah remaja berumur 10-19 tahun adalah sebesar 22,2\% dari total penduduk Indonesia, terdiri $49,1 \%$ perempuan dan $51,9 \%$ laki-laki. Walaupun remaja telah mencapai kematangan kognitif, namun dalam kenyataannya mereka belum mampu mengolah informasi yang diterima tersebut secara benar. Tingkah laku seksual remaja cenderung meningkat atau progresif. Diawali dengan necking (berciuman sampai ke daerah dada), kemudian di ikuti oleh petting (saling menempelkan alat kelamin). Hubungan intim, atau pada beberapa kasus, seks oral, yang secara besar meningkat pada usia remaja selama beberapa tahun belakangan ini. Berdasarkan hasil studi pendahuluan di SMA N 1 Sragi belum mendapatkan pendidikan seks di sekolah dan angka kehamilan tidak diinginkan cukup tinggi yaitu 2 kali dalam satu tahun. Jenis penelitian yaitu deskriptif dengan pendekatan cross sectional. Sampel dalam penelitian ini adalah siswi kelas X dan kelas XI di SMA N 1 Sragi menggunakan teknik sampling proportionate stratified random sampling yaitu 100 responden. Hasil penelitian menunjukkan tingkat pengetahuan remaja putri tentang seks bebas di SMA N 1 Sragi mayoritas responden berpengetahuan kurang berjumlah 40 orang (40\%), pengetahuan baik berjumlah 33 orang (33\%) responden, dan yang mempunyai pengetahuan cukup berjumlah 27 orang $(27 \%)$ responden. Saran untuk pihak sekolah perlu adanya kurikulum tentang Kesehatan reproduksi di sekolah menengah atas
\end{abstract}

Kata Kunci : Remaja putri; Seks bebas

\section{FREE SEX PERCEPTION ACCORDING TO FEMALE STUDENTS IN SMA N 1 SRAGI}

\begin{abstract}
Teenagers are the next generation of family builders. Demographic data shows that adolescents are a large population of the world's population. One fifth of the world's population is a teenager aged 10-19 years. In Indonesia the number of adolescents aged $10-19$ years is $22.2 \%$ of the total population of Indonesia, consisting of $49.1 \%$ female and $51.9 \%$ male. The characteristics of adolescents have reached cognitive maturity. But in this case, they have not been able to process the received information correctly. Teens' sexual behavior is increasing or progressive. Beginning with necking (kissing up to the chest area), then followed by petting (mutual gluing to the genitals). Intimate relationships, or in some cases, oral sex, are greatly increased in adolescence over the past few years. Based on the results of preliminary studies in SMA N 1 Sragi got pregnancy rate and no information about sex education was 2 times higher in a year. The research type was descriptive with cross sectional approach. The sample in this research were students of class X and class XI in SMA N 1 Sragi and used stratified random sampling technique that were 100 respondents. The result of the research shows that the level of knowledge of girls about free sex in SMA N 1 Sragi is less as many as 40 people (40\%), good knowledge 33 people (33\%), and who are knowledgeable are 27 people (27\%). School needs a curriculum on health especially sex education
\end{abstract}

Keywords: Teenagers; Free sex

Jurnal SMART Kebidanan Sekolah Tinggi Ilmu Kesehatan (STIKes) Karya Husada Semarang www.stikesyahoedsmg.ac.id/ojs/index.php/sjkb 


\section{Pendahuluan}

Mempersiapkan sumber daya manusia yang handal dalam rangka mewujudkan keluarga berkualitas di masa datang harus dilakukan sejak mereka masih remaja. Remaja merupakan generasi penerus pembentuk keluarga. Data demografi menunjukkan bahwa remaja merupakan populasi yang besar dari penduduk dunia (Soetjinigsih. 2007).

Menurut Word Health Organitation seperlima dari penduduk dunia adalah remaja berumur 10-19 tahun. Di Indonesia jumlah remaja berumur 10-19 tahun adalah sebesar 22,2\% dari total pe.nduduk Indonesia, terdiri $49,1 \%$ perempuan dan 51,9\% laki-laki (Soetjinigsih. 2007)

Remaja memasuki usia subur dan produktif. Artinya secara fisiologis, remaja telah mencapai kematangan organ-organ reproduksi, baik remaja laki-laki maupun remaja perempuan. Kematangan organ reproduksi tersebut, mendorong individu untuk melakukan hubungan sosial baik dengan sesama jenis maupun dengan lawan jenis. Remaja berupaya mengembangkan diri melalui pergaulan, dengan membentuk teman sebayanya (peer-group). Pergaulan bebas yang tidak terkendali secara normatif dan etika-moral antar remaja yang berlainan jenis, akan berakibat adanya hubungan seksual di luar nikah (Dariyo, 2004).

Walaupun remaja telah mencapai kematangan kognitif, namun dalam kenyataannya mereka belum mampu mengolah informasi yang diterima tersebut secara benar. Remaja yang kurang mampu mengolah informasi tersebut, maka perilaku seksual remaja seringkali tidak terkontrol dengan baik. Mereka melakukan pacaran, kumpul kebo, seks pranikah atau mengadakan "pesta seks" dengan pasangannya, yang menyebabkan kehamilan yang tidak di inginkan, timbulnya penyakit menular seksual di kalangan remaja (Dariyo, 2004).

Tingkah laku seksual remaja cenderung meningkat atau progresif. Diawali dengan necking (berciuman sampai ke daerah dada), kemudian di ikuti oleh petting (saling menempelkan alat kelamin). Hubungan intim, atau pada beberapa kasus, seks oral, yang secara besar meningkat pada usia remaja selama beberapa tahun belakangan ini. Perubahan organ-organ reproduksi yang makin matang pada remaja menyebabkan dorongan dan gairah seksual remaja makin kuat dalam dirinya. Banyak media masa, seperti internet, televisi, koran atau majalah yang menyampaikan informasi secara bebas kepada masyarakat umum, termasuk remaja (Dariyo, 2004)

Salah satu masalah yang cukup pelik yang berkembang di berbagai negara baik negara maju maupun negara berkembang, termasuk Indonesia, ialah terjadinya kehamilan di 
kalangan remaja wanita. Kehamilan merupakan konsekuensi logis dari hubungan pergaulan bebas antara remaja yang berbeda jenis kelamin, yang cenderung tidak bisa dikendalikan dengan baik. Kehamilan di luar nikah merupakan cermin dari ketidakmampuan seorang remaja dalam mengambil suatu keputusan dalam pergaulannya dengan lawan jenis (Dariyo, 2004).

Menurut Gifathiartha (2010) kehamilan tidak di inginkan dapat menimbulkan dampak dalam jangka pendek maupun panjang yang akan merugikan kesehatan. Remaja yang hamil beresiko menderita pre-eklampsi/eklampsi dan disproporsi sefalo pelvic (tulang-tulang panggul belum tumbuh secara sempurna). Kehamilan tidak diinginkan dari beberapa aspek memang mempunyai banyak dampak negatif sehingga pemerintah Indonesia mengeluarkan Undang-undang Perkawinan pasal 7 ayat 1 yang menuliskan bahwa perkawinan hanya diizinkan jika pihak pria sudah mencapai umur 19 tahun dan pihak wanita sudah mencapai umur 16 tahun diharapkan untuk mencapai keluarga yang berkualitas (Gifathiartha, 2010).

Para pemerhati masalah remaja berpendapat, salah satu penyebab seks bebas karena pengetahuan remaja tentang seksualitas masih sangat rendah dan pendidikan seks di sekolah yang tidak memadai. Berbagai cara mereka lakukan untuk mendapat informasi tersebut, seperti melalui teman sebaya yang kebenarannya tidak dapat dipertanggung jawabkan atau melalui berbagai media cetak maupun elektronik yang menyampaikan informasi seks secara vulgar dan bersifat tidak mendidik, tetapi lebih cenderung mempengaruhi dan mendorong perilaku seks yang tidak bertanggung jawab (Pinem, 2009).

Pusat studi kriminologi Universitas Islam Indonesia di Yogyakarta menemukan 26,35\% dari 846 peristiwa pernikahan telah melakukan hubungan seksual sebelum menikah dimana 50\% diantaranya menyebabkan kehamilan (Soetjinigsih. 2007).

Berdasarkan hasil studi pendahuluan yang telah dilakukan di SMA N 1 Sragi didapatkan bahwa siswi di SMA N 1 Sragi belum mendapatkan pendidikan seks di sekolah dan angka kehamilan tidak diinginkan cukup tinggi yaitu 2 kali dalam satu tahun, berdasarkan hasil wawancara yang telah dilakukan oleh peneliti didapatkan 9 dari 12 orang siswi yang ditemui mengatakan bahwa mereka belum pernah mendapatkan pendidikan tentang pendidikan seks bebas, mereka mengatakan informasi yang didapatkan mengenai seksual hanya dari teman sebaya, dari internet dan film porno.

Jurnal SMART Kebidanan Sekolah Tinggi Ilmu Kesehatan (STIKes) Karya Husada Semarang 


\section{Tinjauan Teori}

Pengetahuan dibagi menjadi enam tingkatan yaitu 1) Tahu(know) sebagai mengingat suatu materi yang telah dipelajari sebelumnya, 2) Memahami (comprehension) diartikan sebagai sesuatu kemampuan menjelaskan secara benar tentang objek yang diketahui, dan dapat menginterpretasi objek tersebut secara benar.3) Aplikasi (application) diartikan sebagai kemampuan untuk menggunakan materi yang telah dipelajari pada situasi atau kondisi sebenarnya.4) Analisis (analysis)u suatu kemampuan untuk menjabarkan suatu objek .5) Sintesis (synthesis) merupakan kemampuan untuk menyusun formulasi yang baru. 6) Evaluasi (evaluation) evaluasi ini berkaitan dengan kemampuan untuk melakukan justifikasi atau penilaian terhadap objek (Notoatmodjo, 2003). Pengetahuan dapat dikategorikan: Pengetahuan baik: 76-100\%,Pengetahuan cukup: 56-75\%, Pengetahuan kurang : < 56\% (Arikunto, 2010).

Menurut BKKBN pengertian seks bebas adalah segala cara mengekspresikan dan melepaskan dorongan seksual yang berasal dari kematangan organ seksual, seperti berkencan intim, bercumbu, sampai melakukan kontak seksual, tetapi perilaku tersebut dinilai tidak sesuai dengan norma karena remaja belum memiliki pengalaman tentang seksual (BKKBN, 2007)

\section{Metode Penelitian}

Jenis penelitian yaitu deskriptif dengan pendekatan cross sectional. Populasi dalam penelitian ini adalah semua siswi kelas X dan kelas XI di SMA N 1 Sragi yang berjumlah 280, pengambilan sampel menggunakan teknik sampling proportionate stratified random sampling yaitu 100 responden, istrumen penelitian menggunakan quesioner tertutup dan menggunakan analisis univariat. 


\section{Hasil Penelitian}

Diagram 1. Distribusi frekuensi tingkat pengetahuan responden tentang Sex Bebas

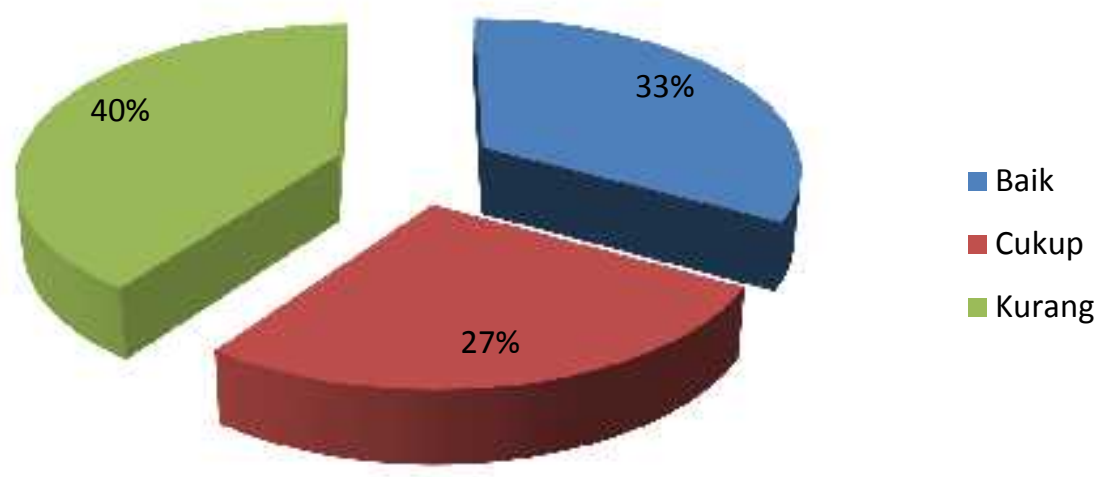

Berdasarkan Diagram 1. dapat dilihat bahwa mayoritas responden mempunyai pengetahuan kurang berjumlah 40 orang (40\%), responden yang mempunyai pengetahuan baik berjumlah 33 orang (33\%), dan responden yang mempunyai pengetahuan cukup berjumlah 27 orang $(27 \%)$.

\section{Pembahasan}

Tingkat pengetahuan seseorang mencerminkan seberapa banyak pengetahuan yang dimiliki orang tersebut. Pengetahuan yang mencakup dalam domain kogntif mempunyai 6 tingkatan yaitu Tahu(know) artinya sebagai recall (memanggil) memori yang telah ada sebelumnya setelah mengamati sesuatu. Memahami artinya tidak sekedar tahu tapi dapat menginterpretasikan secara benar tentang obyek yang diketahui. Aplikasi artinya apabila orang yang telah memahami obyek yang dimaksud dapat menggunakan atau mengaplikasikan prinsip yang diketahui pada situasi yang lain.Analisis yaitu kemampuan seseorang untuk menjabarkan dan atau memisahkan suatu objek, sistesis dimana kemampuan untuk menyusun formulasi yang baru dan evaluasi yaitu kemampuan untuk melakukan justifikasi atau penilaian terhadap suatu objek (Notoatmodjo, 2014).

Pengetahuan seseorang secara langsung akan berpengaruh pada perilaku seseorang, Pengetahuan bisa diperoleh melalui cara tradisional seperti cara coba-salah, cara kekuasaan atau otoritas, berdasarkan pengalaman pribadi serta melalui jalan pikiran dan bisa juga Jurnal SMART Kebidanan Sekolah Tinggi Ilmu Kesehatan (STIKes) Karya Husada Semarang www.stikesyahoedsmg.ac.id/ojs/index.php/sjkb 
melalui cara modern yang lebih sistematis, logis dan ilmiah sedangkan secara umum pengetahuan seseorang terhadap sesuatu hal akan diikuti dengan kesadaran, kemudian rasa ketertarikan, dan berusaha beradaptasi dengan apa yang diketahui (Notoatmodjo, 2014).

Menurut Mubarak (2012) faktor yang mempengaruhi pengetahuan seseorang adalah informasi. Kemudahan untuk memperoleh suatu informasi dapat mempercepat seseorang memperoleh pengetahuan yang baru. Informasi yang diperoleh baik dari pendidikan formal maupun non formal dapat memberikan pengaruh jangka pendek sehingga menghasilkan perubahan atau peningkatan pengetahun. Sebagai sarana komunikasi, berbagai bentuk media masa seperti televisi, radio, surat kabar,majalah dan lain-lain mempunyai pengaruh besar terhadap pembentukan opini dan kepercayaan orang.

Informasi-informasi yang kebenarannya tidak dapat dipertanggung jawabkan melalui berbagai media cetak maupun elektronik yang menyampaikan informasi seks secara vulgar dan bersifat tidak mendidik, dapat atau lebih cenderung mempengaruhi dan mendorong perilaku seks yang tidak bertanggung jawab.

\section{Kesimpulan}

Remaja Putri di SMA N 1 Sragi mayoritas mempunyai tingkat pengetahuan kurang tentang seks bebas.

\section{Saran}

Perlunya ada kurikulum tentang Kesehatan reproduksi di sekolah menengah atas, khususnya di SMA N1 Sragi karena dengan adanya kurikulum tersebut meminimalkan anak-anak remaja melakukan perbuatan seks bebas

\section{Daftar Pustaka}

Arikunto, Suharsimi. Prosedur Penelitian Suatu Pendekatan Praktik Jakarta : Rineka Cipta; 2010 BKKBN (2007), Remaja dan Seks Pranikah

Dariyo, Agoes. 2004. Psikologi Perkembangan Remaja. Cetakan Pertama. Ghalia Indonesia; Bogor

Gifathiartha, Titik. Kehamilan yang Tidak Diinginkan. 2010. Didapat dari: http://kehamilanyang-tidak-diinginkan-ktd.html

Jurnal SMART Kebidanan Sekolah Tinggi Ilmu Kesehatan (STIKes) Karya Husada Semarang 
Hidayat, A.Aziz Alimul. Metodologi Penelitian Keperawatan dan Tehnik Analisis Data. Jakarta : Salemba Medika; 2009

Notoatmodjo, Soekidjo. 2014. Pendidikan dan Perilaku Kesehatan. Cetakan Ke I. Rineka Cipta; Jakarta

Pinem, Saroha. 2009. Kesehatan Reproduksi dan Kontrasepsi. Cetakan Pertama. Nata Wijaya; Jakarta.

Soetjinigsih. 2007. Tumbuh Kembang Remaja dan Permasalahannya Cetakan Ke II. Sagung Seto; Jakarta. 